\title{
Simplex Generic Toponyms in Four English-speaking Jurisdictions
}

\author{
JAN TENT* \\ Linguistics, Macquarie University, Canberra, Australia
}

Toponymic literature generally recognizes three main structures in English: those with a specific + generic element (e.g. Tweed River, Mount White); those that consist of a specific element alone (e.g. Perth, Washington); and less commonly, those with a generic element preceded by the definite article (e.g. The Bend, The Bluff). There are of course combinations and variations on these three (e.g. The Maiden Mountain, Valley of the Giants). Very rarely has the existence of toponyms comprising solely a generic term (e.g. Pinnacle, Sugarloaf) been mentioned or discussed. This survey investigates the occurrence and use of such toponyms in four English-speaking regions.

KEYWORDS specific/generic element, geographic feature term, proprialisation, simplex generic toponyms

\section{On Toponym Structure in General}

Toponyms, as they appear in English, are often considered to be composed of 'SPECIFIC' and 'GENERIC' elements (Kadmon 2002, I2, 24). The specific element is akin to a given name (functioning as the 'identifier'), whereas the generic element is analogous to a classifier or family name, indicating to which class or 'family' the named place belongs (e.g. Botany Bay, River Thames, Rocky Mountains). Generic elements are based on common nouns designating geographic features, and can be referred to as "geographic feature terms" (GFTs). Other authors (e.g. Harvalík 20I2; Room I996) refer to these as "(terrain) appellatives" or simply "generic terms" (Kadmon 2002, I2). ${ }^{\mathrm{I}}$

A very large proportion of toponyms are descriptive, that is, they describe: (a) an inherent characteristic of the geographic feature (i.e. its physical appearance either qualitatively, quantitatively, or metaphorically), e.g. Sandy Creek, The

*School of Literature, Languages \& Linguistics, College of Arts \& Social Sciences, Australian National University, Canberra, ACT 0200, Australia. 
Three Brothers, Mount Dromedary; (b) something associated with the feature or its physical context, e.g. Shark Bay, Powerline Creek, Fishermans Bend; or (c) an event, incident or occasion associated with the feature, e.g. Cape Catastrophe, Easter Island (see Tent \& Blair 20I4 [2009], 20I I). The descriptive constituent of the toponym will naturally form its specific element. Sometimes a toponym may contain a "false generic element" where the GFT may not designate a natural geographic feature (Kadmon 2002, I2), e.g. Watsons Bay, Lake Cargelligo, Castle Hill. Each of these toponyms originally designated natural geographic features, however, after settlements were established at these locations, the names also became associated with their contiguous populated places.

Another class of toponym consists of a specific element alone, perhaps best termed "simplex specific toponyms" (SSTs), e.g. Darwin, London, Boston. ${ }^{2}$ In contrast, there are toponyms that comprise the definite article with an accompanying specific and/or or generic elements, e.g. The Three Sisters, The Armchair, The Basin, The Bight, The Battery Creek, The Bunyip Waterhole. The definite article may be considered to function as (or replace) a specific element, leaving the ensuing GFT to be the expected generic element of the toponym. In this way, the basic SPECIFIC + GENERIC structure is retained. This notion is echoed by Zinkin (1969, I83), declaring "[...] the definite article serves as the specifying element which modifies the generic member".

The grammatical (and pragmatic) function of the definite article in a common noun phrase is to give uniqueness, identifiability or definiteness to nouns (cf. the $\underline{d o g}$ is barking vs a dog is barking). ${ }^{3}$ This identifiability comes from speakers' and listeners' shared contextual knowledge. The same applies to toponyms bearing the definite article. Therefore, when someone refers to the inner Sydney suburb of The Rocks or the Sydney coastal cliff The Gap, for instance, their referents can be immediately identified. Since a toponym must refer to a specific and unique location, the addition of the definite article to a GFT is ostensibly mandatory. Ignoring for the moment the issue of capitalizing the initial letter, in theory at least, unattached GFTs such as basin, breadknife or waterhole cannot normally form toponyms because they are simply seen as common nouns (or appellatives), not proper names. They neither grammatically nor pragmatically identify any particular geographic feature. Considered from this perspective, they are counterintuitive name forms. However, as the ensuing discussion shows, they do exist (e.g. Bluff, Basin, Cliff, River, all appearing in the USA). Helleland $(2002,3)$ terms such toponyms "proprialised terrain appellatives". Another, perhaps more descriptive way of labelling such toponyms is "proprialised simplex GFTs." However, since this is a rather convoluted terminology, and given the fact that they are in essence the converse of SSTs, they shall be referred to here as "simplex generic toponyms" (SGTs).

In order for a common noun GFT to obtain the status of a proper name (i.e. a toponym), it must undergo the process of "proprialisation" (Harvalík 20I2, I 5), or "onymisation" (ICOS n.d., 4), both of which refer to the "transfer of a linguistic unit (including common nouns, adjectives, verbs, interjections, phrases 
etc.) to the class of proper names" (ICOS n.d., 4). Using a similar term, but specifically referring to the process in toponyms, UNGEGN (Kadmon 2007, 4) refers to it as "toponymization", i.e. "The act of producing a toponym from a common noun or other part of speech." Room (I996, IO) refers to the process as the "appellative stage", that is, "the creation of a name from an appellative [which] usually applies when the form or meaning of the name is already present in the appellative, and when the derivation of the name is onymic." By "appellative," Room and Harvalík mean "a common noun, or phrase denoting a number of identical objects, as distinct from a name, that denotes only one." (Room I996, I0). In other words, a proper name uniquely and specifically identifies an individual entity, whilst a common noun designates any one of a particular entity or class. There is therefore, a binary opposition in the onymic and appellative aspects of language.

Proprialisation, in many languages, is not manifested by changes in the structure of the original appellative. In English, for example, the newly formed proper name and the appellative are formally identical, with the exception of the first letter being uppercase for proper names. In Slavic languages though, the difference between homonymous appellatives and proper names is indicated by a change in gender and the declension paradigm (Harvalík 20I2, I I-I2). In any case, it is usually evident from the context of its use whether the term being employed is an appellative or a proper name. Moreover, as soon as an appellative becomes a proper name, it behaves accordingly, observing the rules of the onymic sphere of language.

\section{Data}

\section{Methodology}

The ensuing survey examines and analyzes SGTs in four distinct English-speaking territories: Australia (AU) Canada (CA), New Zealand (NZ), and the United States (US). The reason for choosing these four regions is that they have easily accessible national gazetteers, and that they are all English-speaking countries. Comparisons made between them will increase the likelihood sensible and valid parallels to be drawn, should such exist.

The online gazetteers of Australia (Geoscience Australia 20I6a), Canada (Natural Resources Canada), New Zealand (Land Information New Zealand), and the United States (United States Geological Survey) were used to gather the data for this study. In order to conduct a valid comparison between the jurisdictions, only English SGTs were recorded because the indigenous languages of these regions are too numerous and diverse to draw any meaningful parallels in this instance. The sources used to compile an index of search terms for the gazetteers are:

- AU: Glossary of Generic Terms (Geoscience Australia 2016b); Blair (20I4); Blair and Tent (20I5) 
- CA: Geographical Feature Type (Natural Resources Canada)

- NZ: Generic Geographic Features Listing (Land Information New Zealand)

- US: Feature Class Definitions (U.S. Geological Survey)

Because SGTs referring to non-natural geographic features were found to designate just civic and constructed features, only terms for natural geographic features were included in the index. ${ }^{4}$

The focus of the current survey was to determine how many, if any, SGTs defined natural features. I was particularly interested those SGTs that had retained the original or literal designations for those natural features. This would aid in an understanding of how GSTs come about, and what kinds of natural features were prone to obtaining such a toponymic form. SGTs referring to non-natural features were considered "false generics."

It must be noted that the geomorphology of each jurisdiction has a bearing on the type of GFTs employed. For instance, NZ and the US have numerous fumaroles and geysers (vents in active volcanic areas from which steam, super-heated water, gases and various acids are ejected) (e.g. Lady Knox Geyser and Old Faithful Geyser respectively), and glaciers (e.g. Franz Josef Glacier and Andrews Glacier respectively). In Australia, none of these are found.

Finally, jurisdictions may classify GFTs under dissimilar feature classes or define them differently. ${ }^{5}$ For instance, Geoscience Australia's feature classes are more particularized than those of the USGS - the AU classification distinguishing between HILLs, MOUNTAINs (MTS), and PEAKs, whereas the US schema classifies them all under summits (sums). Table I itemizes some examples where the AU and the US feature classes are defined and classified differently.

Table I reveals substantial differences not only between the USGS and Geoscience Australia's feature classes but also their GFTs. The Australian system has more feature classes, whilst in some instances the USGS has more GFTs. The latter being most likely due to the different geomorphologies of the two regions. The USGS GFTs also contain terms from Spanish and Native American languages. ${ }^{6}$

Where a discrepancy exists between either the meanings of a generic feature class or in the GFTs employed between jurisdictions, a synonymous or suitable alternative term was found when classifying the toponyms in the dataset. Unless, a feature class was unique for a jurisdiction and essential for the sake of clarity, the terms in the Feature Class Definitions for the USA have been employed in this survey.

\section{Results}

The total number of distinct GFTs that have been proprialized and used as SGTs in the four regions was a mere I44. As Table 4 shows, a number of these are duplicated as toponyms (SGTs) for various places, but overall, the total number 
TABLE 1

SELECTION OF SOME FEATURE CLASS CATEGORIES \& ASSOCIATED GFTS IN AU AND US

\begin{tabular}{|c|c|c|c|}
\hline \multicolumn{2}{|l|}{ US } & \multicolumn{2}{|r|}{$\mathrm{AU}$} \\
\hline FEATURE CLASS & GFTs included & FEATURE CLASS & GFTs included \\
\hline \multirow[t]{4}{*}{ CAPE } & \multirow{4}{*}{$\begin{array}{l}\text { lea, neck, } \\
\text { peninsula, point }\end{array}$} & CAPE & cape \\
\hline & & PT & $\begin{array}{l}\text { point, bill, } \\
\text { head } \sim \text { headland, } \\
\text { ness, spit }\end{array}$ \\
\hline & & PEN & peninsula \\
\hline & & PROM & promontory, prong \\
\hline \multirow[t]{3}{*}{ POPL } & \multirow[t]{3}{*}{$\begin{array}{l}\text { city, settlement, } \\
\text { town, village }\end{array}$} & POPL & $\begin{array}{l}\text { hamlet, settlement, } \\
\text { town, } \\
\text { township, village }\end{array}$ \\
\hline & & CITY & city \\
\hline & & SUB & suburb \\
\hline \multirow[t]{2}{*}{ CIVIL } & \multirow{2}{*}{$\begin{array}{l}\text { borough, county, } \\
\text { incorporated place, } \\
\text { municipio, parish, } \\
\text { town, township }\end{array}$} & CNTY & county \\
\hline & & PRSH & parish \\
\hline \multirow[t]{3}{*}{ SUM } & \multirow{3}{*}{$\begin{array}{l}\text { ahu, berg, bald, butte, } \\
\text { cerro, colina, cone, } \\
\text { cumbre, dome, } \\
\text { head, hill, horn, } \\
\text { knob, knoll, mauna, } \\
\text { mesa, mesita, } \\
\text { mound, mount, } \\
\text { mountain, peak, } \\
\text { puu, rock, } \\
\text { sugarloaf, } \\
\text { table, volcano }\end{array}$} & HILL & $\begin{array}{l}\text { hill, hillock, knob, } \\
\text { knoll, kopje, } \\
\text { lookout, } \\
\text { mesa, sugarloaf }\end{array}$ \\
\hline & & MT & mountain \\
\hline & & PEAK & $\begin{array}{l}\text { mountain peak, } \\
\text { peak, summit }\end{array}$ \\
\hline PILR & $\begin{array}{l}\text { chimney, monument, } \\
\text { pinnacle, pohaku, } \\
\text { rock tower }\end{array}$ & ROCK & $\begin{array}{l}\text { needle, pillar, } \\
\text { pinnacle, rock, tor }\end{array}$ \\
\hline
\end{tabular}

Legend: PILR 'pillar', POPL 'populated place', sUM 'summit'.

in the four regions surveyed is still very small. Table 2 shows that such toponyms comprise only a tiny proportion (between $0.03 \%$ and $0.13 \%$ - with a mean of $0.08 \%$ ) of the total number of gazetted toponyms in each jurisdiction, with AU and NZ having the highest proportion of them.

Table 3 summarizes in more detail the results obtained from the data collected. It shows the total number of SGTs in each of the four regions, and the type of geographic feature named (i.e. natural vs. non-natural). Natural features are further divided into those that reflect or express the literal meaning of the proprialised GFT (e.g. AU Reef > REEF; US I I 2x Sugarloaf $\sim$ Sugar Loaf > SUM), and those that express a non-literal meaning of the proprialised GFT (e.g. CA Glacier > WRFL 'waterfall'; NZ Washpool > HILL). As can be seen, the results do not reveal any overt patterns.

The vast majority of SGTs are found in the US (I069-61.6\% of the 1736 total in the four regions), just over twice as many as Australia's 508 (29.3\%), and more than ten times as many as in Canada (5.6\%) and New Zealand $(3.5 \%)$ respectively. Numerically, the US has the most named non-natural 
TABLE 2

PROPORTION OF SGTS OF TOTAL NUMBER OF GAZETTED TOPONYMS IN EACH REGION

\begin{tabular}{llll}
\hline & & \multicolumn{2}{c}{ SGTs } \\
\cline { 3 - 4 } Jurisdiction & Gazetted Toponyms & Frequency & Percentage \\
\hline AU & $370,000+$ & 508 & 0.13 \\
CA & $350,000+$ & 97 & 0.03 \\
NZ & $52,000+$ & 61 & 0.12 \\
US & $2,200,000+$ & 1069 & 0.05 \\
Totals & $2,972,000+$ & 1736 & 0.08 \\
\hline
\end{tabular}

TABLE 3

TOTAL NUMBER OF SGTS BY FEATURE TYPE IN EACH JURISDICTION

\begin{tabular}{|c|c|c|c|c|c|c|c|}
\hline \multirow[b]{4}{*}{ Jurisdiction } & \multirow[b]{4}{*}{ Total SGTs } & \multicolumn{6}{|c|}{ Feature type } \\
\hline & & \multicolumn{4}{|c|}{ Natural } & & \\
\hline & & \multicolumn{2}{|c|}{ Non-literal meaning } & \multicolumn{2}{|c|}{ Literal meaning } & \multicolumn{2}{|c|}{ Non-natural } \\
\hline & & Frequency & Percentage & Frequency & Percentage & Frequency & Percentage \\
\hline$\overline{\mathrm{AU}}$ & 508 & 21 & 4 & 80 & 15 & 408 & 80 \\
\hline CA & 97 & 86 & 89 & 1 & 1 & 10 & 10 \\
\hline NZ & 61 & 13 & 21 & 42 & 69 & 6 & 10 \\
\hline US & 1069 & 10 & 1 & 217 & 20 & 842 & 79 \\
\hline Totals & 1736 & 130 & $7 \cdot 5$ & 340 & 19.6 & 1266 & 72.9 \\
\hline
\end{tabular}

features ( $842-79 \%$ of its I069), however, proportionately Australia has slightly more ( $408-80 \%$ of its 508 ), leaving Canada and New Zealand each with only го\% of such toponyms. Once again, there is no overall discernible pattern to be found in the data as to the referents of the SGTs across the four jurisdictions. Table 3 also shows the US and AU have the most comparable patterns of SGTs. They have the lowest percentage of non-literal meanings, a comparable percentage of literal meanings, and the most designating non-natural features.

Given the fact that only SGTs denoting natural geographic features were the main motivating factor for the survey, ${ }^{7}$ it is interesting to see that overall nearly $73 \%$ of them actually refer to non-natural features, leaving just over $27 \%$ that refer to natural ones. Almost all the non-natural features (e.g. POPLs) in the dataset obtained their names from an adjoining or nearby natural feature bearing that name. Escarpment (POPL) near Niagara Falls, and Estuary (POPL) at the port of Tampa (FL), are clear examples of this phenomenon. Others are the result of a ellipsis of the original name. For instance, the Western Australian town of Boulder is an ellipsis of The Great Boulder, the original name for the gold mining lease, the main features of which were large sandstone boulders in which gold veins were found (Casey \& Mayman 1964). Similarly, the name of Inlet (POPL) in the state of New York (US) is also derived from a former longer name, Inlet on Fourth Lake (United States Geological Survey). 
TABLE 4

MOST COMMON SGTS IN EACH JURISDICTION

\begin{tabular}{|c|c|c|c|c|}
\hline \multirow[b]{3}{*}{ Jurisdiction } & \multirow[b]{3}{*}{ SGT } & \multicolumn{3}{|c|}{ Feature type \& FEATURE CLASS } \\
\hline & & \multicolumn{2}{|c|}{ Natural } & \multirow[b]{2}{*}{ Non-natural } \\
\hline & & $\begin{array}{l}\text { Non-literal } \\
\text { meaning }\end{array}$ & Literal meaning & \\
\hline \multirow[t]{3}{*}{$\overline{\mathrm{AU}}$} & Hillside & & & $118 \mathrm{x}$ HMSD \\
\hline & Hilltop & & & $25 X$ HMSD \\
\hline & Sugarloaf Sugar Loaf & & $\begin{array}{l}51 \times \text { SUM } \\
\quad(37 \mathrm{X} \text { HILL; 14X MT })\end{array}$ & \\
\hline$C A$ & $\begin{array}{l}\text { Sugarloaf Sugar } \\
\text { Loaf }\end{array}$ & 11X LAKE & & \\
\hline \multirow[t]{3}{*}{ NZ } & Pinnacle & & $8 x$ SUM (HILL) & \\
\hline & Pyramid & & $7 X$ SUM (HILL) & \\
\hline & Cone & & 5X SUM (HILL) & \\
\hline \multirow[t]{23}{*}{ US } & Bluff & & & $12 X \mathrm{POPL}$ \\
\hline & Cascade & & & 20X POPL \\
\hline & Cove & & & $14 \times \mathrm{POPL}$ \\
\hline & Dale & & & $20 X$ POPL \\
\hline & Downs & & & 10X POPL \\
\hline & Forest & & & $18 \mathrm{x}$ POPL \\
\hline & Glen & & & $10 X \mathrm{POPL}$ \\
\hline & Grove & & & $17 X$ POPL \\
\hline & Heath & & & 13X POPL \\
\hline & Hillside & & & 33X POPL \\
\hline & Hilltop & & & $43 \times$ POPL \\
\hline & Hot Spring & & 47X SPRG & \\
\hline & Lake & & & $12 \mathrm{X}$ POPL \\
\hline & Oxbow & & & 11X POPL \\
\hline & Pinnacle & & 22X SUM; $10 \mathrm{X}$ ROCK & \\
\hline & Ridge & & & $14 X \mathrm{POPL}$ \\
\hline & Rock & & & 11X POPL \\
\hline & Sugarloaf Sugar Loaf & & $112 \mathrm{X}$ SUM & \\
\hline & Summit & & & 38x LOC; 53X POPL \\
\hline & Vale & & & $10 X$ POPL \\
\hline & Valley & & & $11 X$ POPL \\
\hline & Wood & & & 11X POPL \\
\hline & Woods & & & $13 X \mathrm{POPL}$ \\
\hline
\end{tabular}

Legend: HMSD 'homestead', LOC 'location/locale', SPRG 'spring'.

Often names of well-known geographic features are also truncated. This is sometimes exhibited with mountains, e.g. Everest, Kilimanjaro, Matterhorn, Erebus, Kosciuszko, Ruapehu, Tarawera etc. Such constructs are suggestive of hypocoristic names, or the personification of such features. Other prominent or conspicuous features also experience such name pruning, but only when the truncated name cannot be confused with another feature, e.g. Old Faithful (Geyser), (Lake) Eucumbene, Sow and Pigs (Reef), Kakadu (National Park) etc. The ellipsis in these instances results in what will be termed here as a "simplex specific toponym" (SST).

Other truncated names may be derived from GFTs that form the specific element of toponyms inspired through metaphoric analogy because the feature 
resembles something manufactured or occurring in the natural world. Toponyms such as Sugarloaf, Needle, Oxbow, Pyramid, Pillar, Saddle etc. may have resulted from the ellipsis of Sugarloaf Mountain, Needle Rock, Oxbow Lake, Pyramid Hill, Pillar Rock, Saddle Pass, etc. Sugar Loaf Mountain in Maryland, not far from Washington DC, is such a case, with the US Geological Survey listing Mont de Sugarlov, Pain de Sucre, Sugarloaf, and Sugarloaf Mountain as permissible name variants. Technically, of course, truncated names of this sort are not SGTs but SSTs. Nevertheless, I shall maintain the label SGT for such toponyms given such appellatives generally function as GFTs. In addition, gazetteers (the sources for the data in this survey) generally do not provide etymologies or origins of toponyms so it is not always possible to determine whether the gazetted name or names are the result of an ellipsis. In addition, it cannot be assumed that all the toponyms collected in this survey were derived directly from GFTs. Some may be eponymous, named after individuals with personal names such as Brook, Dale, Downs, Heath etc. Such SGTs always designate habitative features. Initially, however, these personal names would most likely have been derived from GFTs.

Table 4 catalogues the most common SGTs in each jurisdiction. With the exception of NZ, only feature classes which have ten or more examples are included in the table.

Table 4 shows that two thirds $(66.3 \%)$ of SGTs embody GFTs for non-natural geographic features ( $n$. 537: 273). However, what is noteworthy is that 22 $(73.3 \%)$ of the 30 most common SGTs refer to hypsographic feature terms (i.e. for relief features), I 6 of which $(72.7 \%)$ represent orographic feature terms (i.e. for elevated features). It seems therefore that orographic features tend to produce more SGTs than most other GFTs. This seems reasonable because it is precisely these elevated features that stand out in the surrounding landscape from other feature types. The remaining eight SGTs exemplify vegetation feature types ( $n .4$ or $\mathrm{I} 3.3 \%)$ and water feature types $(n .4$ or $\mathrm{I} 3.3 \%)$. Of the orographic features, Sugarloaf Sugar Loaf produces the most common SGT, with I74 instances across the jurisdictions AU, CA and US. Hillside is the next most popular with I 5 I instances across AU and US.

Why Sugarloaf is the most common SGT for any natural geographic feature in the dataset (5IX SUM in AU; I IX LAKE in CA; and II 2 X SUM in the US) seems intriguing. Notwithstanding the enigma of the I I lakes bearing that moniker in CA, the ${ }_{1} 63$ instances in AU and the US designating summits stands to reason. In a forthcoming paper, I attempt to answer why Sugarloaf is such a popular SGT (see in Tent 2020, forthcoming).

Table 5 displays the most common feature classes of SGTs in each jurisdiction. The most common ones being for non-natural features ( $n$. I 236 or $76.3 \%$ ); among them $65 \mathrm{I}$ POPLS, I 84 LOCS, and in the US, and 226 HMSDs in AU. This is interesting given the original appellatives upon which these SGTs are based all denote natural geographic features. The link between them is revived if there is 


\begin{tabular}{lllr}
\hline & & FEATURE CLASS & \\
\cline { 2 - 4 } Jurisdiction & Natural & Non-natural & Frequency \\
\hline AU & & HMSD & 226 \\
& & LOC & 53 \\
& & TRIG & 47 \\
& & PRSH & 49 \\
& HILL & POPL & 16 \\
CA & & 52 \\
& MT & & 18 \\
& LAKE & POPL & 5 \\
NZ & & 29 \\
STRM & & 15 \\
US & PT & LOC & 9 \\
& & & 5 \\
& HILL & POPL & 47 \\
& & LOC & 651 \\
& SUM & & 184 \\
& SPRG & & 142 \\
& ROCK & & 51 \\
& BEND & & 10 \\
& IS & & 6
\end{tabular}

Legend: IS 'island', REGN 'region', STRM 'stream', TRIG 'triangulation station/pillar'.

some kind of connection between the named object and the appellative whose name forms are homonymous.

The proprialised appellatives comprising the SGTs in the dataset can be morphologically classified into six types:

a. monomorphemic, e.g. Creek, Rock

b. bimorphemic (free morpheme + inflectional suffix), e.g. Cliffs, Hills

c. bimorphemic (free morpheme + derivational suffix), e.g. Anchorage, Escarpment

d. bimorphemic (solid compound-free morpheme + free morpheme), e.g. Hillside, Sugarloaf

e. bimorphemic (open compound-free morpheme \& free morpheme), e.g. Jump Up, Sugar Loaf

f. a combination of $(\mathrm{d}) /(\mathrm{e})+(\mathrm{b})$, e.g. Tablelands

The majority ( $n$. II 5 or $80 \%$ ) of the I 44 distinct proprialised appellatives are types $(\mathrm{a}),(\mathrm{b})$ or $(\mathrm{c})$, the other $20 \%(n=29)$ are of types $(\mathrm{d}),(\mathrm{e})$ and $(\mathrm{f})$. These latter types are analogous in form to toponyms with standard SPECIFIC + GENERIC structures, either in solid or open compound forms, such as Rutherglen, Bankstown, Forestville, Mossvale, and Lane Cove, Violet Town, Moss Vale, etc. It is perhaps because of this analogous SPECIFIC + GENERIC structure that such forms are disposed to become proprialised. This, however, still leaves the question as to why types (a), (b) and (c) are more often proprialised. 


\section{Discussion \& Conclusion}

The literature on the nature of proper names is extensive (see van Langendonck 2007 for a comprehensive bibliography). However, very few authors have directly addressed the phenomenon of SGTs or any other kind of simplex generic name (e.g. Dog the name of John Wayne's dog in the I97 I movie “Big Jake”). Kepsu (I997, I 8 ) for instance, lists types of vicinity names, the first of which he labels "topographical terms (location)", and although the examples he provides are Finnish settlement names, they have their origins in GFTs, e.g. Mummi and Malm 'heath', Labti and Vik 'bay', and Kullo 'hill'.

Kadmon (2000, 4I) also briefly mentions their existence, although my research shows he has somewhat overestimated their frequency: "In a not inconsiderable number of cases a generic term itself constitutes a toponymy, oftenthough not always - of simplex form." And Anderson (2007, 309-310) comes close to it when he discusses 'generic names' (i.e. names that have pragmatic generic reference) when he states: "Genericness is apparently at odds with the individualization associated with names," which he suggests are based on [common] nouns. However, it is perhaps not surprising that SGTs and simplex generic names (in the sense I use the term in this article), have largely eschewed examination in onomastic literature, perhaps due to their general scarcity.

Matthews (2018) does discuss SGTs in some, though not great, detail. In a paper investigating New Zealand's toponyms, using a revised version of UNGEGN's inferred four-tiered model for toponyms (see Kadmon 2002, 2007), he argues the UNGEGN model has several short-comings. One is that UNGEGN does not recognize "generic element simplex geonames consist[ing] of one or more morphemes or words that form only a generic element" (Matthews 20I 8, IOI), in other words, SGTs. Matthews schematizes the inferred UNGEGN model as in Figure I, and shows his revised and expanded model as in Figure 2:

The left-hand branch of the "terrestrial geoname [geographical name]" node or member of Figure 2, has one member, viz. "simplex geoname", which in turn has two leaves of the same rank (i.e. peers), viz. "with only a specific element" and "with only a generic element". The latter acknowledges the existence of SGTs as described above.

Matthews also includes in his 'simplex geoname with only a generic element' category items such as The Basin, The Bight, etc. If my contention (and that of Zinkin I969), as articulated above, concerning such toponyms is accepted, these forms cannot be considered as simplex given they consist of two constituents (a GENERIC and a preposed definite article functioning as a SPECIFIC). In support of this argument, we see that UNGEGN (Kadmon 2002, I8, I9) distinguishes between "composite" and "simplex names" the former consisting of a generic and specific element, or of a specific element consisting of more than one word, and the latter of a specific component only. In addition, Room (I996, 25, 92) differentiates between "composite names" (one-word names comprising at least two morphemes); "compound names" (consisting of at least two components or 


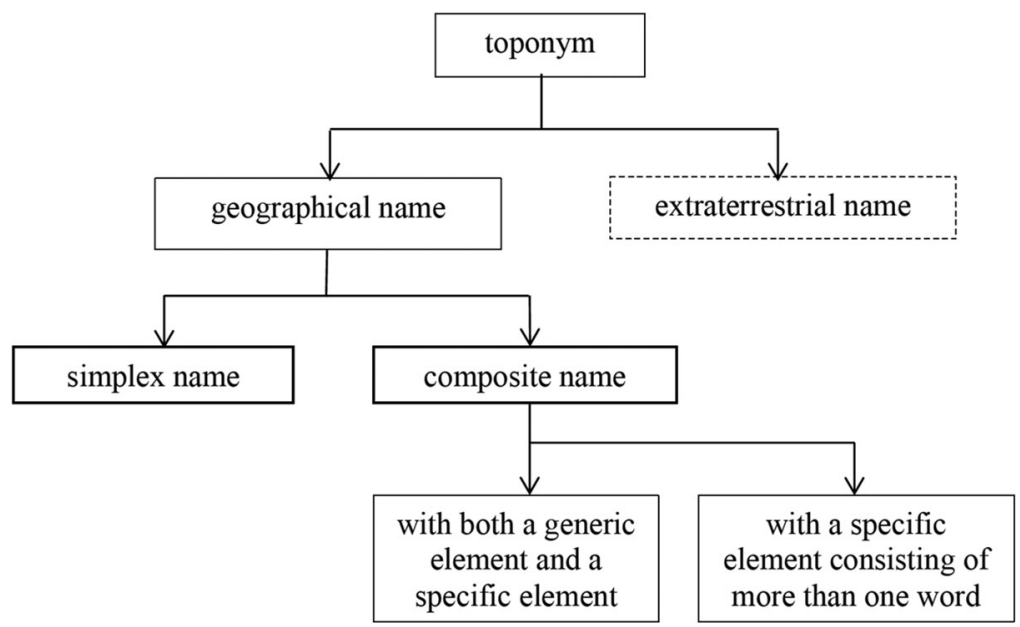

FIGURE 1. Matthews' schematization of UNGEGN's inferred four tier toponym model (Source: Matthews 2018).

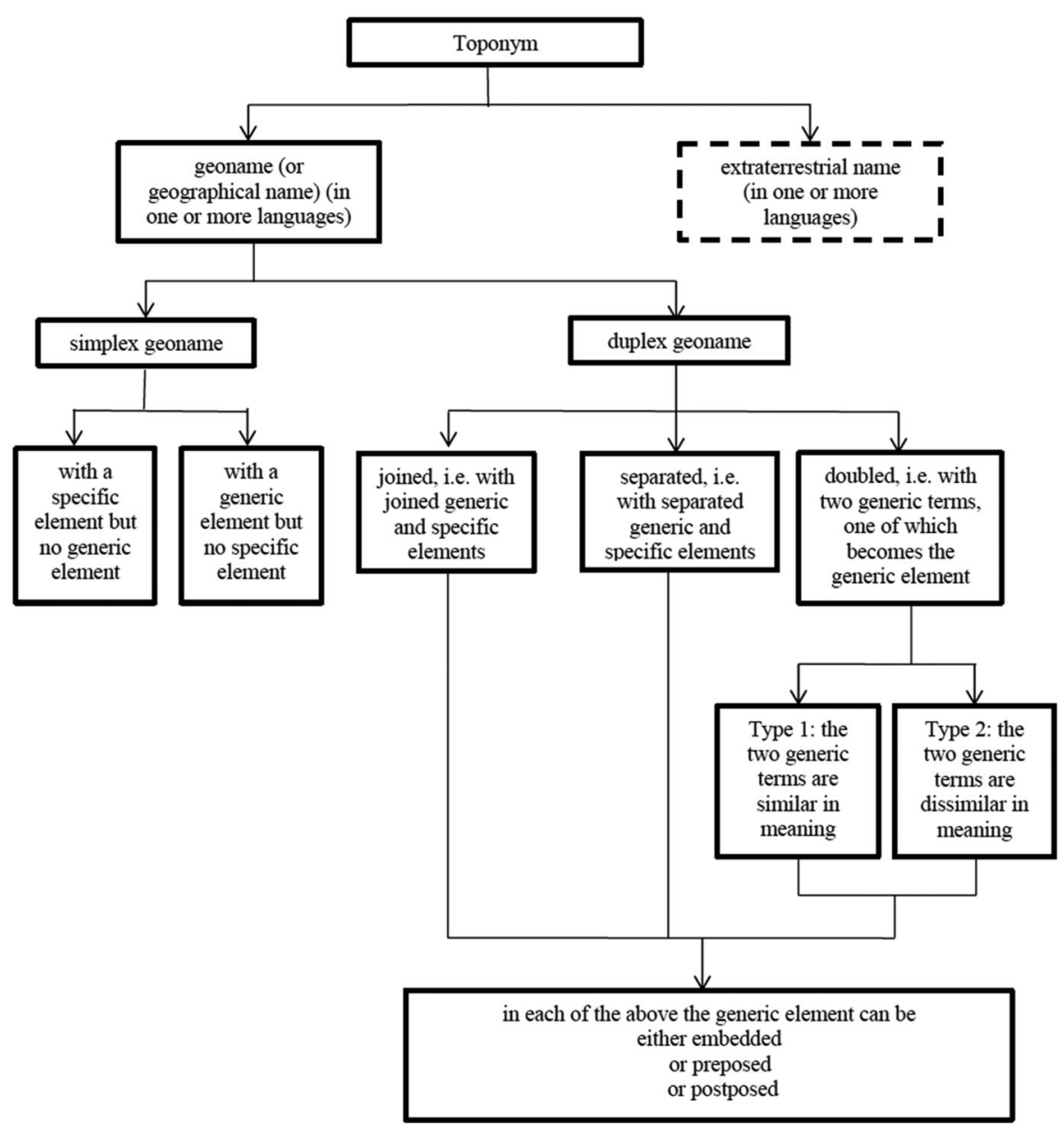

FIGURE 2. Matthews' revised inferred UNGEGN toponym model (Source: Matthews 2018). 
two separate hyphenated words); and "simplex names" (consisting of a single component). Lastly, van Langendonck and van de Velde (2016, 34) categorize toponyms into four sets: those with "zero marking" (London, Berlin); those with "suffixing" (Fin-land, German-y); those with "preposed articles" (the Highlands, The Rhine), and those with a "classifier", and possibly an article (the North Sea, the Gobi Desert). It does not appear that toponyms like The Basin and The Bight are classified as "simplex" in any of other toponymic literature. Notwithstanding this minor technical disparity between Matthews' inclusion of GFTs with toponyms with preposed articles, he nevertheless recognizes that SGTs form as a distinct class of toponym, which makes for a useful contribution to toponymic studies.

If SGTs are found in AU, CA, NZ and the US, it is only reasonable to assume that they also occur in other regions of the world and languages. A cursory examination of a number of published articles, gazetteers, and placename dictionaries bears this out, e.g. Gazetteer of British Place Names (Association of British Counties), The Concise Oxford Dictionary of English Place-Names (Ekwall I947), Dictionary of Southern African Place Names (Raper et al. 2014), Nederlandse Plaatsnamen-Herkomst en Historie ['Dutch Placenames-Origins and History'] (van Berkel \& Samplonius 2006), NIS Gazetteer - France (CIA I964), Places in the World-France (Markowski n.d.), Tongan Place Names (Gifford I923), New Zealand Gazetteer (Land Information New Zealand), and Matthews (20I8). As with many of the English toponyms in AU, CA, NZ and US, many of the SGTs in the UK, South Africa, the Netherlands, France, and Tonga, are Locs or POPLs, in other words, habitative toponyms. No doubt many of these will have taken their names from neighboring natural geographic features, and in some instances are likely to be the result of an ellipsis of their original name forms. Clearly, a more systematic investigation is warranted to examine SGTs in other countries.

What this small survey has shown is that SGTs constitute a distinct class of toponym not only in English-speaking regions, but also in other regions and languages. They seem to be quite universal, and hence, deserve not only to be recognized as a discrete toponym class, but also warrant further investigation.

\section{Notes}

I. I draw a distinction between (a) "generic term", i.e. a common noun designating a type of topographic feature, and (b) "generic element", i.e. that part of a toponym that consists of a generic term. A "generic term" should be viewed in the same light as a common noun, a lexical item that can be defined grammatically or morphologically. By comparison, a "generic element" should be seen as an element of a toponym (proper name) that functions as a classifier.

2. There are numerous other toponymic forms, including: solid compounds, e.g. Rutherglen, Bankstown, Forestville, Brookvale, Alberton, Ellendale; hyphenated compounds, e.g. Tomato- $\overline{\text { Stick }}$ Cave, Boba-Day Park, Brighton-Le-Sands; open compounds that include binomials, e.g. Coal and Candle Creek, Sow and Pigs 
Reef, Linger and Die Creek; participial forms, e.g. Rotten Swamp, Unnamed Corner, Disputed Plain, Felled Timber $\overline{\text { Creek, }}$ Rising Fast Creek, Murdering $\overline{\text { Creek; }}$; phrases, e.g. Chain of Ponds, Valley of the Giants, Leg of Lamb $\overline{\text { Bank, Butt of }}$ Liberty (РT), Run o' Waters Creek, Bust Me Gall Hill, Meeting of the Waters (LOC), etc.

3. Quirk et al. (I985, 265 ff.) distinguish between "specific" and "generic reference" when dealing with article use in English. In the former, a particular specimen, individual or object is being referred to; in the latter, no particular reference to a specific individual or object is signified.

4. Natural features include: Hydrographic features (marine \& inland water),

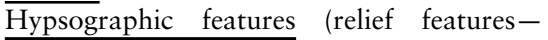
elevated \& non-elevated), and Vegetation \& Desert features. Non-natural features include: Constructed features (those which are the result of human artifice on the topography), and Civic features (those which are administrative and conceptual).

5. UNGEGN defines "feature class" as a "[g]rouping of topographic features with similar characteristics, to facilitate classification, search and retrieval. Example: river, creek, brook, wadi etc., all classed under 'stream'." (Kadmon 2002, 7). Feature classes operate at a higher level of abstraction than GFTs themselves, and each is labelled with an alpha code of $2-5$ characters. Most can be manifested by more than one GFT, e.g. backwash, brook, burn, creek, river, rivulet, run, etc. come under the feature class STRM.

6. None of which were found to comprise SGTs in the US.

7. Terms for civic features such as: canal, dam, mine, park reserve, tower, municipality, parish, province are excluded.

\section{Disclosure statement}

No potential conflict of interest was reported by the author(s).

\section{Bibliography}

Anderson, J. M. 2007. The Grammar of Names. Oxford: Oxford University Press.

Association of British Counties. 20I I-20I9. "Gazetteer of British Place Names." Accessed August 20 I9. http://gazetteer.org.uk.

Blair, D. and J. Tent. 2015. "Feature Terms for Australian Toponymy." ANPS Technical Paper No. 3. South Turramurra: Placenames Australia. http://www.anps.org.au/upload/ANPSTechPaper3.pdf.

Blair, D. 20I4. "A Standard Geographic Feature Catalogue for Toponymic Research.” ANPS Technical Paper No. I. Version 3.I. South Turramurra: Placenames Australia. http://www.anps.org.au/upload/ ANPSTechPaperi.pdf

Casey, G., and T. Mayman. 1964. The Mile that Midas Touched. Adelaide: Rigby.

CIA. I964. NIS Gazetteer - France. Vol. II. M-Z. Washington DC: Office of Geography, Department of Interior.

Ekwall, E. 1947. The Concise Oxford Dictionary of English Place-Names. 3rd ed. London: Oxford University Press.

Geoscience Australia. 20I6a. "Gazetteer of Australia." Commonwealth of Australia. Accessed August 20I9. http://www.ga.gov.au/placename.

Geoscience Australia. 2016b. "Glossary of Generic Terms.” Version I.o. Prepared by the Committee for Geographical Place Names in Australia. Intergovernmental Committee on Surveying and Mapping. Accessed August 2019. https://icsm.gov.au/sites/default/files/2017-09/glossarypnames.pdf.

Gifford, E. W. 1923. Tongan Place Names. Bernice P. Bishop Museum Bulletin 6. Bayard Dominick Expedition Publication Number 7. Honolulu: Bernice Pauahi Bishop Museum.

Harvalík, M. 20I2. "Appellativisation and Proprialisation: The Gateways between the Appellative and Proprial Spheres of Language." In Name and Naming: Synchronic and Diachronic Perspectives, edited by O. Felecan, IO-I7. Newcastle upon Tyne: Cambridge Scholars Publishing.

Helleland, B. 2002. "The Social and Cultural Value of Place Names." Paper presented at the Eighth United Nations Conference on the Standardization of Geographical Names Berlin, 27 August-5 September. E/ 
CONF.94/CRP.ro6. Accessed September 2019. https://unstats.un.org/unsd/geoinfo/UNGEGN/docs/8thuncsgn-docs/crp/8th_UNCSGN_econf.94_crp.ro6.pdf.

ICOS. 20I9. "List of Key Onomastic Terms." Accessed August 20I9. https://icosweb.net/wp/wp-content/ uploads/20I9/05/ICOS-Terms-en.pdf.

Kadmon, N. 2000. Toponymy: The Lore, Laws and Language of Geographical Names. New York: Vantage Press.

Kadmon, N., ed. 2002. Glossary of Terms for the Standardization of Geographical Names. ST/ESA/STAT/ SER.M/85.. New York: Department of Economic and Social Affairs Statistics Division, United Nations Group of Experts on Geographical Names (UNGEGN).

Kadmon, N., ed. 2007. Glossary of Terms for the Standardization of Geographical Names: Addendum. ST/ ESA/STAT/SER.M/85/Add.I. New York: Department of Economic and Social Affairs Statistics Division, United Nations Group of Experts on Geographical Names (UNGEGN). Accessed August 20I9. https:// unstats.un.org/unsd/geoinfo/UNGEGN/docs/pubs/glossaryadde.pdf.

Kepsu, S. I997. "Vanhakylä." In You Name It: Perspectives on Onomastic Research, edited by R. L. Pitkänen and K. Mallat, I I6-I27. Studia Fennica Linguistica 7. Helsinki: Finnish Literature Society.

New Zealand Gazetteer. 20I9. "Land Information New Zealand-Toitū te whenua." New Zealand Gazetteer. Accessed August 20I9. https://gazetteer.linz.govt.nz.

Markowski, A. 2019. "Places in the World-France." Accessed August 2019. http://france.places-in-theworld.com/index.html.

Matthews, P. W. 2018. "The Structure of New Zealand Geonames: A Preliminary Study Based on an Enhanced Version of UNGEGN's Geonames Model.” Onomastica Canadiana 97, no. I \& 2: 97-I40.

Natural Resources Canada. 20I6. "Canadian Geographical Names Data Base (CGNDB)." Accessed August 20I9. http://www4.rncan.gc.ca/search-place-names/search?lang=en.

Quirk, R., S. Greenbaum, G. Leech, and J. Svartvik. I985. A Comprehensive Grammar of the English Language. London: Longman.

Raper, P. E., L. A. Möller, and L. T. Du Plessis. 20I4. Dictionary of Southern African Place Names. Johannesburg, Cape Town: Jonathan Ball Publishers.

Room, A. 1996. An Aphabetical Guide to the Language of Name Studies. Lanham, MD: Scarecrow Press Inc.

Tent, J. 2020, forthcoming. "The Sugarloaf.” ANPS Occasional Paper. South Turramurra: Placenames Australia (Inc.).

Tent, J., and D. Blair. 20II. "Motivations for Naming: The Development of a Toponymic Typology for Australian Placenames." Names 59, no. 2: 67-89.

Tent, J. and D. Blair. 20I4 [2009]. "Motivations for Naming: A Toponymic Typology.” ANPS Technical Paper, No. 2. Revised Edition. South Turramurra: Placenames Australia (Inc.). www.anps.org.au/upload/ ANPSTechPaper2.pdf.

U.S. Geological Survey (USGS). "Feature Class Definitions.” Accessed August 20I9. https://geonames.usgs. gov/apex/f? $\mathrm{p}=\mathrm{I} 38: 8$..

van Berkel, G., and K. Samplonius. 2006. Nederlandse Plaatsnamen-Herkomst en Historie [Dutch Placenames-Origins and History]. Utrecht: Prisma, Het Spectrum.

van Langendonck, W. 2007. "Theory and Typology of Proper Names." In Trends in Linguistics Studies and Monographs I68, edited by W. Bisang, H. H. Hock \& W. Winter. Berlin: Mouton de Gruyter.

van Langendonck, W., and M. van de Velde. 20I6. "Names and Grammar." In The Oxford Handbook of Names and Naming, edited by C. Hough, I7-38. Oxford: Oxford University Press.

Zinkin, V. I969. "The Syntax of Place-names.” Names: A Journal of Onomastics I7, no. 3: I8 I-I 98. 


\section{Notes on contributor}

Jan Tent is a retired academic and current Director of the Australian National Placenames Survey. He is also an Honorary Senior Lecturer at the Australian National University, Canberra, and an Honorary Research Fellow at Macquarie University, Sydney. Jan's onomastic research has mainly concentrated on early European place-naming practices in Australasia, as well as the toponymy of Australia in general.

Correspondence to: Jan Tent, Linguistics, Macquarie University, Canberra, ACT, 2600, Australia. E-mail: jan.tent@anu.edu.au 